"An application of a Chartered Institute of Management Accounting strategy on stock control: a case of the South African municipality"

\section{AUTHORS}

ARTICLE INFO

Zwelihle Wiseman Nzuza

Zwelihle Wiseman Nzuza (2016). An application of a Chartered Institute of Management Accounting strategy on stock control: a case of the South African municipality. Public and Municipal Finance, 5(2), 30-39. doi:10.21511/pmf.5(2).2016.03

DOI http://dx.doi.org/10.21511/pmf.5(2).2016.03

RELEASED ON JOURNAL Tuesday, 06 December 2016 "Public and Municipal Finance"

FOUNDER
NUMBER OF REFERENCES

0

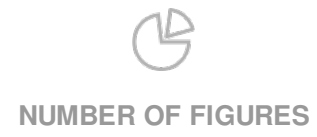

0

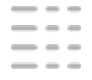

NUMBER OF TABLES

0

(C) The author(s) 2022. This publication is an open access article. 


\title{
An application of a Chartered Institute of Management Accounting strategy on stock control: a case of the South African municipality
}

\begin{abstract}
The aim of the study is to demonstrate how best a municipal stock control can be applied in conformity with strategic requirements of the Chartered Institute of Management Accounting (CIMA). A quantitative research method was applied. The questionnaire was formulated based on information obtained from the literature, and was distributed to only one KwaZulu-Natal (KZN) local government department. The sample consisted of 82 respondents, selected using a census sampling method. The results indicate that the stores department lack CIMA stock control strategies, leading to poor stock control policy formulation and application. Staff experience and the effect of municipal stock control policy have shown a positive and significant relationship at .000* level. Proper documentation of strategic stock control and staff experience has also shown a positive significant relationship at $.004 *$ level. Moreover, the municipal strategic stock control framework has been proposed at the end of this paper and is subject to further experiments by the scholars.
\end{abstract}

Keywords: stock control, stock control policy, stock control strategies.

JEL Classification: H54, M40.

\section{Introduction}

Stock is the heart of any organization, because it serves as one of the multiple investments that the business could have. Therefore, a study of the stock control leads one through many interesting side trails. Stock control starts in the ancient times with such interesting records of management accounting. It is, therefore, very important to start by laying a good foundation of management accounting before talking about the stock control. Management accounting has a historical background that stretches back longer than one might expect and certainly accounting historians have not yet concluded their investigations of its earliest genesis (Chatfield, 2013, p. 1977). According to the International Federation of Accountants (IFAC) $(2002$, p. 8), there is a period before the first management accounting revolution which is known as the "classical period" and ended in the late 1950s. Before 1820, the term management accounting was not known, but the term used to define processes for the computation of costs and for financial control was "cost accounting" (Hoskin \& Maeve, 2014, p. 1988). Johnson \& Kaplan (1987) and Jonsson \& Mattsson (2008, pp. 1788-1789) reveal that the first management accounting systems were integrated by North American cotton textile factories that were established after 1812. They used cost accounts to ascertain the direct labor and overhead costs of converting stock/raw material into yarn and fabric. From the late 1950 s to the early 1980 s, the first management accounting revolution which became known as the "modern management accounting period" had started (Chenhall \& Langfield-Smith, 2014,

(C) Zwelihle Wiseman Nzuza, 2016.

Zwelihle Wiseman Nzuza, Lecturer, Department of Management Accounting, Durban University of Technology, Durban, South Africa. p. 1998). During this period, modern management accounting was deeply rooted in the Ford Foundation's initiative to restructure management accounting aspects in the United States (Freedman, 2012). During the second half of the 19th century, British accountants became determined to acquire professional status and, in 1853, the Edinburgh Society and the Glasgow Institute of Accountants were formed. Several professional accounting bodies were subsequently founded on the model of the Scottish institutes (Shotter, 2001, pp. 261-263). The second management accounting revolution took place between 1980 and 1999. At this time, management accounting educators and researchers came about discovering that the influence of mathematical modeling on the development of management accounting did not serve the purpose of business managers at the workplace (Chenhall \& LangfieldSmith, 2014, p. 1998). In 1987, leading management accounting researchers like Johnson and Kaplan called for three considerations in management accounting: (1) extending management accounting into nonfinancial areas, (2) a better understanding of contemporary problems and the information needs of managers, and (3) innovative practices (Fleischman \& Parker, 2013, p. 165). CIMA has a broad stream of accounting which combines a stock control and other functions by management in the planning, decision making, and control of the activities in the organization. Management accounting is governed by the body called Chartered Institute of Management Accountants (CIMA) that operates in Ireland as a division of British body (Jonsson \& Mattsson (2008, p. 1788). CIMA has always been one of the smallest body and has a small number of members including students. In 2015, CIMA had about 227000 of both the members and students in 179 countries. CIMA is also a member of the International Federation of Accountants and is the only 
one leading professional body of management accountants in the world and has a mission to help people and organizations to succeed in the public and private sectors (CIMA, 2015). Although there has been a large body of research generated in stock control in an international context, studies that investigate how best a stock control can be applied at a CIMA strategic level are somewhat few, use limited data, or have narrow focus. While municipal stock control may be faced with occasional serious increasing rates of qualified audit reports, none of the municipalities have considered the need to address the problem.

The overall aim of this research was to demonstrate how best a stock control can be applied at a CIMA strategic level. A case of the KwaZulu-Natal Municipality, South Africa. The specific objectives of the research were three: (1) to investigate staff understanding of stock control, (2) to investigate effects of the existing municipal stock control strategies; and (3) to demonstrate how best a stock control can be applied at a CIMA strategic level.

\section{Municipal stock control}

Before we define municipal stock control, let us understand first what municipal stock is. CIMA refers to International Accounting Standard (IAS) No. 2 to define stock/inventory. It defines as all assets, both tangible and intangible, held for sale in the ordinary course of business, in the process of manufacturing for such sale, or are consumed during the manufacturing of saleable goods or services (Du Toit, Jodwana, Mungal, Du Plessic \& Panicker, 2016, p. 46). Umzimvubu municipality (2016, p. 5) also defines stock as "assets in the form of material or supplies to be consumed in the production process, in the form of materials or supplies to be consumed or distributed in the rendering of services, held for sale or distribution in the ordinary course of operations, or in the process of production for sale or distribution". Secondly, before we define stock control, let us understand what is meant by "control". Control means transposition of theory into practical exercise. Now we can define stock control. Stock control is a process in which the materials and parts carried in stock are regulated within predetermined limits or set in accordance with the policy and procedures implemented or adopted by the organization (Hailing \& Guochao, 2011, pp. 1-2).

\section{Legal framework}

The Municipal Financial Management Act (MFMA), Act No. 56 of 2003 is an official framework for controlling the finances of a municipality including the unauthorized, irregular, and fruitless spending on stocks or inventories. The MFMA framework stipulates that stock control is carried out by the Stores Division in conjunction with the requirements of the Preferential Procurement Policy Framework Act (PPPFA), Act No. 5 of 2000, which governs the control of the municipal stocks (Nzuza, 2015, p. 17).

\section{Municipal stock valuation}

Municipal stock valuation is the process of assigning costs to stocks. Stock costs may include costs incurred while ordering, holding (i.e., warehousing and logistics costs, insurance cost, spoilage cost, handling cost, and depreciation) and distributing stock. Stock-out cost includes sales that are lost due to stock shortages, both in short and long-term. Ordering costs are incurred when placing stock orders. Warehousing and logistics costs are incurred to pay rent, labor, and utilities. Insurance cost is incurred to insure the stock costs against theft, losses, and destruction. Spoilage cost includes cost to write off stock due to it being spoiled or broken and unable to be sold. Handling cost refers to the costs of moving materials and products from one place to another. Depreciation is a non-cash cost and it refers to the depreciation cost of machinery and plant used in managing the stock in the stores (Singh, Sahu \& Nayak, 2012, p. 297). There are two commonly used methods to calculate the value of stock, namely, first in first out (FIFO) and weighted average method. Both these methods can be applied within the municipality to two different stock systems, either a perpetual stock system and a periodic stock system depending on its stock policy and the type of stock its hold. When using FIFO method, the first stocks received by the municipality are the first to be issued or sold and the stock costs follow the physical flow of the stock. Under a weighted average method, the stock items are issued or sold at the average price calculated until a new purchase changes the average price. Perpetual stock system relies upon occasional physical count of the stock to determine the value of the stock on hand at the year end. Periodic stock system entails that a stock count to determine the value of the stock on hand takes place at specific intervals (Du Toit et al., 2016, pp. 47-48).

\section{Stock recording process}

Stock recording is a process which starts from receiving of stock to storeroom of stock and lastly to dispatching of stock by the municipality (Du Toit et al., 2016, p. 46). This process can be demonstrated as follows: 


\begin{tabular}{|l|l|l|l|l|l|l|}
\hline $\begin{array}{l}\text { Quotation from } \\
\text { supplier }\end{array}$ & $\begin{array}{l}\text { Purchase } \\
\text { requisition }\end{array}$ & & Purchase order & Goods received note \\
\hline \multicolumn{2}{|l|}{ Stores issues TO Units } & $\begin{array}{l}\text { Goods received note } \\
\text { by Units }\end{array}$ \\
\hline $\begin{array}{l}\text { Quotation from } \\
\text { Units }\end{array}$ & $\begin{array}{l}\text { Purchase } \\
\text { requisition }\end{array}$ & $\begin{array}{l}\text { Purchase order } \\
\text { by Units }\end{array}$ & \\
\hline
\end{tabular}

Fig. 1. Municipal stock control accounting

Source: self-generated.

When stock is purchased from suppliers, the following accounting journal entries must be passed.

Table 1. Stock purchases

\begin{tabular}{|l|l|l|l|l|}
\hline Dt & Purchases & & XXXX & \\
\hline $\mathrm{Ct}$ & Bank/creditors & & & XXXX \\
\hline & Stock purchased & & \\
\hline
\end{tabular}

Table 1 illustrates that acquisitions of stock are to be debited and bank or creditors be credited in the accounting entries of the organization. When stock is sold to customers, the following accounting journal entries must be passed.

Table 2. Stock issues

\begin{tabular}{|l|l|l|l|l|}
\hline Dt & Bank/debtors & & XXXX & \\
\hline $\mathrm{Ct}$ & \multicolumn{1}{|l|}{$\mid$ Purchases } & & & XXXX \\
& Stock sold & & & \\
\hline
\end{tabular}

Stock control accounting helps to ensure proper recording of the stock flows so that at the end of the day, cost of stock sold, as well as cost of stock on hand will be known. Table 2 shows that the stock issues to customers are to be credited and bank or debtors account be debited in the accounting entries of the organization.

\section{Reasons for holding stock}

There are three reasons why the municipality may choose to keep stock on hand for a short-term period or long-term period. Du Toit et al. (2016, p. 55) outline three reasons as follows:

5.1. Transactional. This means that municipality holds stock to use in its daily manufacturing process. Moreover, since the lead time for suppliers is not always the same, the municipality, therefore, should keep enough stock on hand to ensure that daily tasks can commence without any shortages of stock.

5.2. Precautionary. This is stock that is kept in times of uncertainty, also referred to as safety stock.

5.3. Speculative. If the municipality suspects that there will be a price increase, it will order more stock at the current lower cost. If there is going to be a price de- crease, then, the municipality will keep its stock at the minimum level until the price decrease occurs.

\section{Application of common strategy on stock control}

Singh et al. (2012, p. 297) define common stock control strategy as a general way of including the arrangements of resources required to achieve stock control objectives. It extends its function up to a corporate strategy level of a cascade of plans for the various functions and divisions and serves as a statement of long-term goals along with a definition of the strategies and policies which will ensure achievement of these goals. Common stock control can be summarized as how municipalities create and sustain superior general strategic performances. Davies (1985, p. 12) as cited by Chenhall \& Langfield-Smith (2014, pp. 1998), defines common stock control as knowing the strategy one proposes to carry out. Common strategy component involves general policy/strategy formulations and political policy analysis and it has a link with planning, leadership, and decision making. From these definitions, it could be clearly drawn and concluded that common stock control strategy is used as a craft of figuring out which purposes are worth pursuing and capable of being accomplished in order to achieve a set of goals in a specific time and it not ground on management accounting theories (Tabatoni, Davies \& Barblan, 2010, pp. 6-7).

6.1. Stock policy. Stock policy can be defined functionally to mean: a clear single decision or group of decisions which may set out directives for guiding future decisions, initiate or retard action, or guide implementation of previous decisions. Stock policies, however, differ in terms of their scope, complexity, decision environment, range of choices, and decision criteria (Haddad, 1995, pp. 17-18). EU-Project $(2003$, p. 9) is in view that due to complexities in stock policy formulation in municipalities, it is, therefore, essential to break the policy structure down into smaller parts, which are easier understandable. 


\section{Conceptual framework for stock policy anal- ysis}

According to Haddad (1995, p. 23), stock policy analysis model consists of eight policy planning processes, the first five of which deal with policy making, the sixth with planning, the seventh and eighth with policy adjustment. These can be shown as follows:

7.1. Stock policy maker. In social sciences, there are two essential dimensions of policy making: (1) who does it; (2) and how. Due to complexities in policy making, policy analysts have recently introduced two types of models: (1) the organizational (public interest) model; (2) the personalistic (selfinterest) model. The practice element has swung between a synoptic (comprehensive) tactic and an incremental approach. The synoptic tactic is a one single central planning authority for the whole of humanity, combining economic, political and social control into one unified planning process that makes interface pointless. Incremental policy approach, on the other hand, disparages synoptic technique in that it depends on interface rather than on a synoptic tactic (EU-Project, 2003, p. 9).

7.2. Analysis of the existing situation. Stock policy analysis should consider numerous contexts, such as control application, staff competency, stock costs (i.e., ordering costs, holding costs) and even the internal environment factors. These factors have obvious implications for stock policy formulation in that different internal environmental factors will have different values about the role of stock control (Haddad, 1995, p. 24).

7.3. The generation of stock policy options. Stock policy options can be created in several dissimilar ways to minimize the disparities. According to Haddad (1995, pp. 30-32), this may be done in following nine ways:

7.3.1. Systemic mode. Characterization of the systemic mode may prove it to be impractical. Reason being, its data are usually derived from two sources: sector analysis and the existing body of professional knowledge. In a sector analysis, a large number of options can be generated to fit the different observations of the sector and its context, whereas in the use of existing body of professional knowledge, a variety of intellectual, political, social and professional constraints limit the range of stock policy options.

7.3.2. Incremental mode. This is sometimes referred to as the "acting out" approach whereby the policymaker seeks to adjust present difficulties rather than to anticipate future ones, thereby promoting incremental improvements.
7.3.3. Ad hoc mode. Here the stock policy may have no rational basis within the organization, but may require the whole control system to make necessary transformations or changes.

7.3.4. Importation mode. This mode describes a foreign imported approach. A certain stock policy adopted elsewhere can be imported successfully only if it meets the needs of particular groups in the organization or if an importer is involved.

7.3.5. Evaluation of stock policy options. Stock policy options can be evaluated only if alternative scenarios are available to allow estimations of the likely implications of the option considered. The estimated situation is to be compared with the present situation and the transition from the existing to the estimated situation is evaluated in terms of desirability, affordability and feasibility (Haddad, 1995, pp. 32-34).

7.3.6. Making the stock policy decision. The variety of conflicting interests claims that the stock policy which is selected causes compromizes among many stakeholders. The selected policy shall not be in favor of any single interest group, but shall have a broad base of support which will be needed to take the policy from the drawing board to implementation (Haddad, 1995, p. 35).

\subsubsection{Planning for stock policy implementation.} This can be defined as a sequence of analytical and evaluative procedures to formulate an intended strategy and the means of implementing it and staying competitive (Ofori \& Atiogbe, 2012, p. 69). A detailed information as to who will do what, when and how; allocation of physical resources must be made clear so that implementation delays are minimal. This can be achieved in the following 3 ways: (1) the personnel needed to put plans into action must be freed from other commitments so that they may pay fully attention, (2) any technical knowledge needed for policy implementation must be understood by those who will employ it and (3) the administrative systems involved shall be visibly structured and firmly in place (Haddad, 1995, p. 35). Planning of policy implementation is a rigorous and critical brainstorming session used by the top management to steer the affairs of the organization. In other words, policy planning (Ofori \& Atiogbe, 2012, p. 71) entails setting visions and missions, goals and objectives; clarifying policies and principles; and searching for opportunities, threats, strengths and weaknesses (SWOT).

7.3.8. Stock policy impact assessment. The sooner accurate assessment takes place, the sooner stock policy makers can know if their creativities are working as projected or certain adjustments are required (Haddad, 1995, pp. 37-38). 
7.3.9. Subsequent stock policy cycles. If a policy was carried out systematically, the process of policy design, planning, implementation, impact assessment and redesigning will become iterative, and, in theory, infinitely (Haddad, 1995, p. 38).

\section{Research methodology}

A literature review was used as the source of information from which to formulate the questionnaire, which consisted of closed-ended questions.

8.1. Population. A questionnaire was used to collect data from 96 staff members regarding their views on the practicality of application of CIMA strategic stock control. The study was confined to the procurement section of a municipal department, and this population was selected for investigation, because it was relevant in the practices of a municipal inventory stock control.

8.2. Questionnaire administration. The standardized, self-administered questionnaire comprised a general section for biographical information. Another section dealt practical application of CIMA strategic stock control. A mix of nominal items in the questionnaire was employed in the biographical section. Apart from the demographics, all variables were measured using a 3-point Likert scale. The researcher collected a total of 96 responses (82 full and 14 partially completed questionnaires). The 14 partially completed questionnaires were discarded, resulting in a final sample of 82 .

8.3. Data analysis. Using descriptive and inferential statistics, data were analyzed using the Statistical Package for Social Sciences (SPSS) version 21.0. In order to test relationships, the crosstabulations with appropriate inferential statistics (Chi-square test) were used. Reliability tests performed by this study were conclusive for all the ordinal questionnaire items (Cronbach's alpha > $0.5)$. The survey's data also fully passed the validity test, as all Likert scale items split into exactly 24 components. All tests were performed with a confidence level of 0.798 , thus, concluding that the reliability of the study was acceptable.

\section{Results and findings}

The biographic details such as gender, age, qualification, and experience of the respondents are shown in Table 3.
Table 3. Biographic data

\begin{tabular}{|l|c|c|}
\hline & Frequency & Percent \\
\hline Gender: & & \\
\hline Male & 50 & $61 \%$ \\
\hline Female & 32 & $39 \%$ \\
\hline Total & 82 & $100 \%$ \\
\hline Age: & & \\
\hline $10-20$ years & 9 & $11 \%$ \\
\hline $21-30$ years & 17 & $21 \%$ \\
\hline $31-40$ years & 35 & $43 \%$ \\
\hline 41 years and above & 21 & $25 \%$ \\
\hline Total & 82 & $100 \%$ \\
\hline Qualification: & & \\
\hline Secondary education & 20 & $25 \%$ \\
\hline Diploma & 47 & $57 \%$ \\
\hline Degree & 9 & $11 \%$ \\
\hline Honours & 3 & $4 \%$ \\
\hline Masters & 2 & $2 \%$ \\
\hline Doctorate & 1 & $1 \%$ \\
\hline Total & 82 & $100 \%$ \\
\hline Experience: & & \\
\hline $0-5$ years & 21 & $26 \%$ \\
\hline $6-10$ years & 17 & $21 \%$ \\
\hline 11 years and above & 44 & $53 \%$ \\
\hline Total & 82 & $100 \%$ \\
\hline
\end{tabular}

Of the 82 respondents, 61 percent were male, while 39 percent were female. The results indicate the imbalance of gender. With regard to the respondents' ages, the study revealed that the majority (43 percent) were between 31 and 40 years, 25 percent ranged from 41 years and above, 21 percent were between 21 and 30 years, and 11 percent were between 10 and 20 years. In terms of the highest qualifications of the study respondents, the survey established that the majority (57 percent) of the respondents had a diploma, 25 percent had secondary education, 11 percent had a degree qualification, 4 percent had honours qualification, 2 percent had a master's qualification and 1 percent had a doctoral qualification. This suggests that all study respondents had adequate educational qualifications to enable them to answer the survey instrument, but the members of staff need to be encouraged to further their studies (National Treasury Republic of South Africa, 2001). Regarding years of service, the survey established that the majority of the respondents (53 percent) have worked for 11 years and above, 26 percent have worked for 0 to 5 years, while 21 percent of the respondents have worked for 6 to 10 years. This points to the fact that most of the respondents were experienced, since they had worked long enough to be conversant with the operations of stock control.

Table 4. Understanding of stock control

\begin{tabular}{|l|c|c|}
\hline & Agree & Neutral \\
\hline The term 'first in first out' (FIFO) means that the first stocks received are the first to be issued or sold. & 38.60 & 43.86 \\
\hline $\begin{array}{l}\text { The term 'weighted average' means that the stock items are issued or sold at the average price calculated } \\
\text { until a new purchase changes the average price. }\end{array}$ & 29.82 & 38.60 \\
\hline
\end{tabular}


Table 4 (cont.). Understanding of stock control

\begin{tabular}{|l|c|c|}
\hline & Disagree & Neutral \\
\hline $\begin{array}{l}\text { Perpetual stock system relies upon occasional physical count of the stock to determine the value of the } \\
\text { stock on hand at the year end. }\end{array}$ & 36.84 & 42.11 \\
\hline $\begin{array}{l}\text { Periodic stock system entails that a stock count to determine the value of the stock on hand takes place at } \\
\text { specific intervals. }\end{array}$ & 38.60 & 43.86 \\
\hline
\end{tabular}

Table 4 shows that the majority of the respondents (43.86 percent) was not sure about FIFO definition. 38.60 percent agreed with FIFO definition and 17.54 percent disagreed with the definition. Concerning the definition of the weighted average method, the majority of the respondents (38.60 percent) was not sure, 31.58 percent disagreed and 29.82 percent agreed with the definition. In the same way with the definition of a perpetual stock system, the majority of the respondents (42.11 percent) was not sure, whereas 36.84 percent agreed and 21.05 percent disagreed with the statement. Period stock system was also not known with only 38.60 percent of the respondents agreed with the definition and 17.54 percent disagreed with the statement. The results have proved that the majority of staff is not well trained and they require very stringent stock control skills.

Table 5. Stock control strategies

\begin{tabular}{|l|c|c|c|}
\hline & Agree & Neutral & Disagree \\
\hline I understand the goals of stock control system that is used. & 31.58 & 8.77 & 59.65 \\
\hline There is clear stock management software. & 31.58 & 19.30 & 49.12 \\
\hline There is a performance indicators for stock control. & 24.56 & 19.30 & 56.14 \\
\hline Stock control strategies are made at an executive level. & 63.16 & 21.05 & 15.79 \\
\hline A detailed information as to who will do what, when and how is made available in the stock planning. & 53.86 & 12.81 & 33.33 \\
\hline A choice to choose a re-order point resides with the Stores Division. & 81.58 & 5.60 & 12.82 \\
\hline Our department give supports to all staff for their career development. & 15.79 & 36.84 & 47.37 \\
\hline My department has an option to change its stock control policy. & 22.81 & 42.11 & 35.09 \\
\hline Clear stock labels are created for each stock item. & 80 & 0 & 20 \\
\hline The terms and conditions of the current stock policy are fair to everyone. & 71.93 & 8.77 & 19.30 \\
\hline A point-of-sale (POS) inventory management method is used. & 43.86 & 38.60 & 17.54 \\
\hline Stock documents is stored in an organized manner. & 61.58 & 8.60 & 29.82 \\
\hline Stock count is performed manually. & 30.33 & 12.81 & 56.86 \\
\hline Stock count is performed several times a month. & 22.56 & 19.30 & 58.14 \\
\hline Stock control policy is normally assessed for its efficacy. & 31.58 & 21.05 & 47.37 \\
\hline
\end{tabular}

Table 5 shows that the majority of the respondents (59.65 percent) disagreed that they understand the goals of stock control system that is used. 31.58 percent agreed and 8.77 percent of the respondents was not sure with the statement. In terms of whether there is clear stock management software, the majority of the respondents (49.12 percent) agreed, 31.58 percent disagreed and 19.30 percent of the respondents was not sure if there is. More than a half of the respondents (56.14 percent) disagreed that the organization has a stock control performance indicators, 24.56 percent agreed and 19.30 percent of the respondents was not sure about the statement. The municipal stock control strategies are made at an executive level (63.16 percent). Hence, a detailed information as to who will do what, when and how is made available in the stock planning. A choice to choose a re-order point resides with the Stores Division though (81.58 percent). The department, however, does not support those members of staff who further their education levels. The department is hesitant to change its stock control policies. This may be because of the MFMA Act which is very strict in terms of how the municipal finances should be managed. Even though a stock control policy is not frequently assessed for efficacy, but the terms and conditions of a municipal stock policy are fair. This is because of a point-of-sale (POS) stock management method which is used (43.86 percent) and that stock documents are stored in an organized systematic manner which allows the organization for keeps track.

Chi square tests. The Chi square test was performed to determine whether there was a statistically significant relationship between the variables (rows vs columns). The null hypothesis states that there is no association between the two. The alternate hypothesis indicates that there is an association.

Table 6. The results of the Chi square tests

\begin{tabular}{|l|l|c|c|}
\hline \multicolumn{1}{|c|}{ Statements } & Age & Qualification & Experience \\
\hline Stock control strategy has been clearly documented. & $.001^{*}$ & $.007^{\star}$ & $.004^{\star}$ \\
\hline There are enough resources to secure stock/inventory. & .266 & .940 & $.001^{\star}$ \\
\hline
\end{tabular}


Table 6 (cont.). The results of the Chi square tests

\begin{tabular}{|l|c|c|c|}
\hline \multicolumn{1}{|c|}{ Statements } & Age & Qualification & Experience \\
\hline There is a performance indicators for stock control. & .265 & .922 & $.016^{*}$ \\
\hline Stock control strategies are made at an executive level. & .075 & .215 & .119 \\
\hline $\begin{array}{l}\text { A detailed information as to who will do what, when and how is critically discussed during } \\
\text { stock planning. }\end{array}$ & .065 & $.030^{*}$ & $.004^{*}$ \\
\hline Our department give support to staff members who further their education levels. & .012 & $.003^{\star}$ & $.031^{*}$ \\
\hline My department has an option to change its stock control policy. & .965 & $.010^{*}$ & .411 \\
\hline The terms and conditions of the current stock policy are fair. & .398 & $.041^{\star}$ & $.008^{\star}$ \\
\hline Stock control policy is normally assessed for its efficacy. & $.021^{*}$ & .500 & $.000^{*}$ \\
\hline
\end{tabular}

A significant result is indicated with " $\mathrm{p}<0.05$ ". These values are highlighted with a *.

A departmental stock control strategy has a significant relationship with the respondents' age, qualification and experience. This means that the higher the age $(.001 *)$, the qualification $(.007 *)$ and the experience $\left(.004^{*}\right)$, the more one understands that the departmental stock control vision. Stock control planning has a significant relationship with experience at $.004 *$ level. This means that the higher the experience, the more one could be able to grasp an understanding of the organizational stock control planning. Staff experience has a significant relationship with an assessment of stock control policy at $.000 *$ level. This means that the higher the experience the higher the probability that a staff member can be able to conduct a stock control policy assessment over a period of time.

\section{CIMA stock control strategy analysis models}

CIMA (2005, p. 3) analysis of stock control strategy can be defined as the use of various tools to prepare strategies by evaluating the opportunities and challenges faced by the organization, as it moves forward with cost management principles. CIMA stock control strategy analysis is known as the identification and evaluation of data relevant for strategy formulation which is followed by decision making. The following strategies are CIMA analysis models for business stock control:

10.1. Make or buy. Make or buy decision is the act of deciding in the middle of making a product by yourself or buying it from someone outside. Municipalities all over the world are faced with that challenge. Municipalities use stock differently depending on the type of the organization. But most commonly, municipalities buy the stock from their suppliers of stock for two main reasons: to trade it at cost to it units for consumption; and to use it for community infrastructure upgrades. In this case, municipalities may decide to outsource or manufacture the stock for themselves depending on the cost factor. If resources are available and cheaper than outsourcing, then, it may decide to make it in house (du Toit et al., 2016, pp. 380-383).

10.2. Break-even analysis. Break-even analysis is a short-term decision technique that is anxious with the relations concerning selling price, sales and stock volume, costs and profit. This technique is an answer to determine the number of stocks required to be sold to break-even. This means that even so with the required levels of production, break-even is an answer. Municipalities should not hold more than the required stocks, as this will be subject to stock being stolen and burring excessive holding costs. One of the advantages of applying break-even analysis is that the number of stock required is the same as the number of stock to be sold, yielding to no stock on hand by the organization (Bajec \& Jakomin, 2012, p. 287).

10.3. Product mix. Product mix in management accounting is also referred to as product assortment which means the number of product lines that an organization offers to its clients. Product mix is a collection of interconnected cost objects produced by a single business. In order for the business to be engaged in a product mix market, relevant product flow information needs to be scrutinized thoroughly. This may include available labor force (including managers) and their hours, number and quality of machinery and its available hours, availability of materials needed, suppliers, budget, organizational structure, product demand, government, and other value adding factors such as environmental considerations, including Kings III report (Kim \& Park, 2013, pp. 4-6).

10.4. Economic order quantity. "Is a model which seeks to quantify the most economic order size which will result in the lowest total cost of stock policy applied by an organization" (du Toit et al., 2016, p. 64). The model helps organizations to deal with matters of re-order point, minimum stocks and maximum stock required, and safety stock calculation.

10.5. Material requirement planning (MRP). This technique quantifies the amount of stock to be ordered based on a master manufacturing schedule, by means of a bill of stock or inventory grade information (Chenhall \& Langfield-Smith, 2014, p. 1997).

10.6. Just in time (JIT). Basically, this technique seeks to enforce time management in that stock should be ordered and delivered on time when it is needed. This may, in fact, require that an organization have a good relationship with the suppliers of 
stock and that operations within the organization are well established and work effectively (du Toit et al., 2016, p. 64).

10.7. Other general considerations by CIMA. CIMA has a range of analytical methods that can be employed in stock control: SWOT analysis, PEST analysis, Porter's five forces analysis, four corner's analysis, value chain analysis, early warning scans, and war gaming. SWOT is an acronym for strengths, weaknesses, opportunities, and threats. SWOT prioritizes the internal and external factors so that time is spent concentrating on the most significant factors. SWOT ensures that the stock control risks or high impact threats and opportunities are clearly identified and are dealt with in priority order. PEST stands for political, economic, social, and technological. PEST analysis is a scan of the external macro-environment in which an organization exists. Porter's five forces analyze the five forces such as the suppliers' power, buyers' power, competitive rivalry, threat of substitution, and threat of new entry. This theory was developed in 1979 by Michael E. Porter of Harvard Business School. Porter's five forces identifies where power lies in the organization. By understanding where power lies, it can be used to identify areas of strength, improve weaknesses and avoid possible future mistakes. Four corners analyze the four aspects: (1) future goals; (2) current strategy; (3) assumptions and (4) capabilities. This theory was originally pioneered by Michael Porter. The last one is value chain analysis. Value chain analysis has two stages: (1) separate the organization's operations into primary and support activities and (2) allocate cost to each activity.

\section{Proposed stock control strategy framework for municipal stock control}

Figure 2 (see Appendix) shows that a successful stock control strategy can be modeled after taking into account the following considerations:

- Stock policy maker - who is the policy maker in the organization?
- Analysis of the existing situation - what are the actual existing conditions of the environment?

- The generation of stock policy options - how can stock control policy be generated?

- Evaluation of stock policy options - when, how, and who shall evaluate stock control policy?

- Making the stock policy decision - when, how, and who shall make the decisions pertaining to stock control?

- Stock policy impact assessment - is the impact measurable?

- Subsequent stock policy cycle - is current policy be subjected to change in the future?

\section{Conclusion}

Research was conducted to investigate how best stock control can be applied at CIMA strategic level, with specific reference to the KwaZulu-Natal (KZN) Province. The role played by CIMA members in organizations in cost management is generally well recognized today. Stock control is one of their key priorities. Poor stock control has created an atmosphere of cautions, mainly among the local municipalities and government. Since, in most instances, the government do not deal directly with the society, but through local municipalities, a clear line of stock control responsibility should be demarcated, e.g., in the form of a linear responsibility chart. Tactics, such as make or buy, break-even analysis, product mix, EOQ, MRP, JIT, and other general considerations by CIMA should be used to break down non-value adding activities assignable to stock control. The study reflects poor staff training, poor stock control strategies from implementation to operation. Based on the results, the study recommends that a supporting staff development and internal control systems of the organization be established. The proposed strategic stock control framework serves as a calling to every interested researcher to come and join me in the area of municipal stock control improvement, not that the current policies are bad, but the users of such policies require both academic and practical advancements.

\section{References}

1. Bajec, P. \& Jakomin, I. (2010). A make-or-buy decision process for outsourcing. Promet-traffic \& transportation, 22 (4), p. 287.

2. Chenhall, R. \& Langfield-Smith, K. (2014). Adoption and benefits of management accounting practices: An Australian study, Management accounting research, 9 (1), pp. 1-19.

3. CIMA. (2005). Key approaches and trends in strategy: Topic gateway series. Available at: http://www.cimaglobal.com/Documents/ImportedDocuments/cid_tg_key_approaches_and_trends_in_strategy_dec 07.pdf.pdf (accessed 13 April 2016).

4. CIMA. (2015). Key approaches and trends in strategy: Topic gateway series. Available at: http://www.cimaglobal.com/Study-with-us/CIMA-Professional\%20Qualification/management\%20accountantgateway/ (accessed 11 May 2016).

5. Chatfield, M. (2013). A history of accounting thought. Robert E. Krieger Publishing Company: New York.

6. Du Toit, E., Jodwana, T., Mungal, A., du Plessic, A. \& Panicker, M. (2016). Cost and management accounting: Fundamentals $-A$ Southern African approach. $1^{\text {st }}$ ed. Cape Town: Juta \& Company Ltd. 
7. EU-Project. (2003). Policy formulation and implementation. Available at: http://www.eltis.org/sites/eltis/files/kt9b_wm_en_6.pdf (accessed 4 March 2016).

8. Fleischman, R.K., Hoskin, K.W. \& Maeve, R.M. (2013). The boulton \& watt case: The ClUX of alternativeapproaches to accounting history? Accounting and business research, 25 (99), pp. 164-165.

9. Freedman, J.M. (2012). Learn from the past, Management accounting (IMA).

10. Haddad, W.D. (1995). Education policy-planning process: an applied framework. Available at: http://www.unesco.org/education/pdf/11_200.pdf (accessed 4 March 2016).

11. Hailing, D. \& Guochao, J. (2011). Limit distribution of inventory level of perishable inventory model, Mathematical problems in engineering, 1 (1), pp. 1-2.

12. Hoskin, K.W. \& Maeve, R.H. (2014). The genesis of accountability, The west point connections, accounting, organizations and society, 13 (1), pp. 37-73.

13. International Federation of Accountants. (2002). International standard setting in the public interest. Available at: https://www.ifac.org/system/files/publications/files/international-standard\%20setting-in-the-public-interest.pdf (accessed 11 May 2016).

14. Jonsson, P. \& Mattsson, S.A. (2008). Inventory management practices and their implications on perceived planning performance, International journal of production research, 46 (7), pp. 1788-1789.

15. Johnson, H.T. \& Kaplan, R.S. (1987). Relevance lost: the rise and fall of management accounting. Harvard business school press: Boston.

16. Kim, S. \& Park, G. (2013). Relevant costs in product mix decision making. Available at: http://gebrc.nccu.edu.tw/proceedings/APDSI/2004/pdf/046.pdf (accessed 22 May 2016).

17. Nzuza, Z.W. (2015). Factors affecting the success of inventory control in the stores division of the eThekwini Municipality, Durban: a case study. M Tech. Durban University of Technology. South Africa.

18. Ofori, D. \& Atiogbe, E. (2012). Strategic planning in public universities: A developing country perspective, Journal of management and strategy, 3 (1), p. 69.

19. Singh, T., Sahu, S.K. \& Nayak, A.K. (2012). An EOQ model for a deteriorating item with time dependentquadratic demand and weibull distribution deterioration under permissible delay in payment, Advances in theoretical \& applied mathematics, 7 (3), pp. 295-297.

20. Shotter, M. (2001). Is management accounting theory breaking free from the shackles of neo-classical economics? A South African perspective, Meditari accountancy research, 9 (1), pp. 261-263.

21. Tabatoni, P., Davies, J. \& Barblan, A. (2010). Strategic management and universities institutional. Available at: http://www.eua.be/eua/jsp/en/upload/Strategic_Manag_Uni_institutional_Devlpt.1069322397877.pdf (accessed 11 May 2016).

22. Umzimvubu municipality. (2016). Inventory/stock management policy. Available at: http://www.umzimvubu.gov.za/Financial/Policies/Documents/Inventory\%20management\%20policy\%202016.pdf (accessed 6 May 2016). 
Appendix

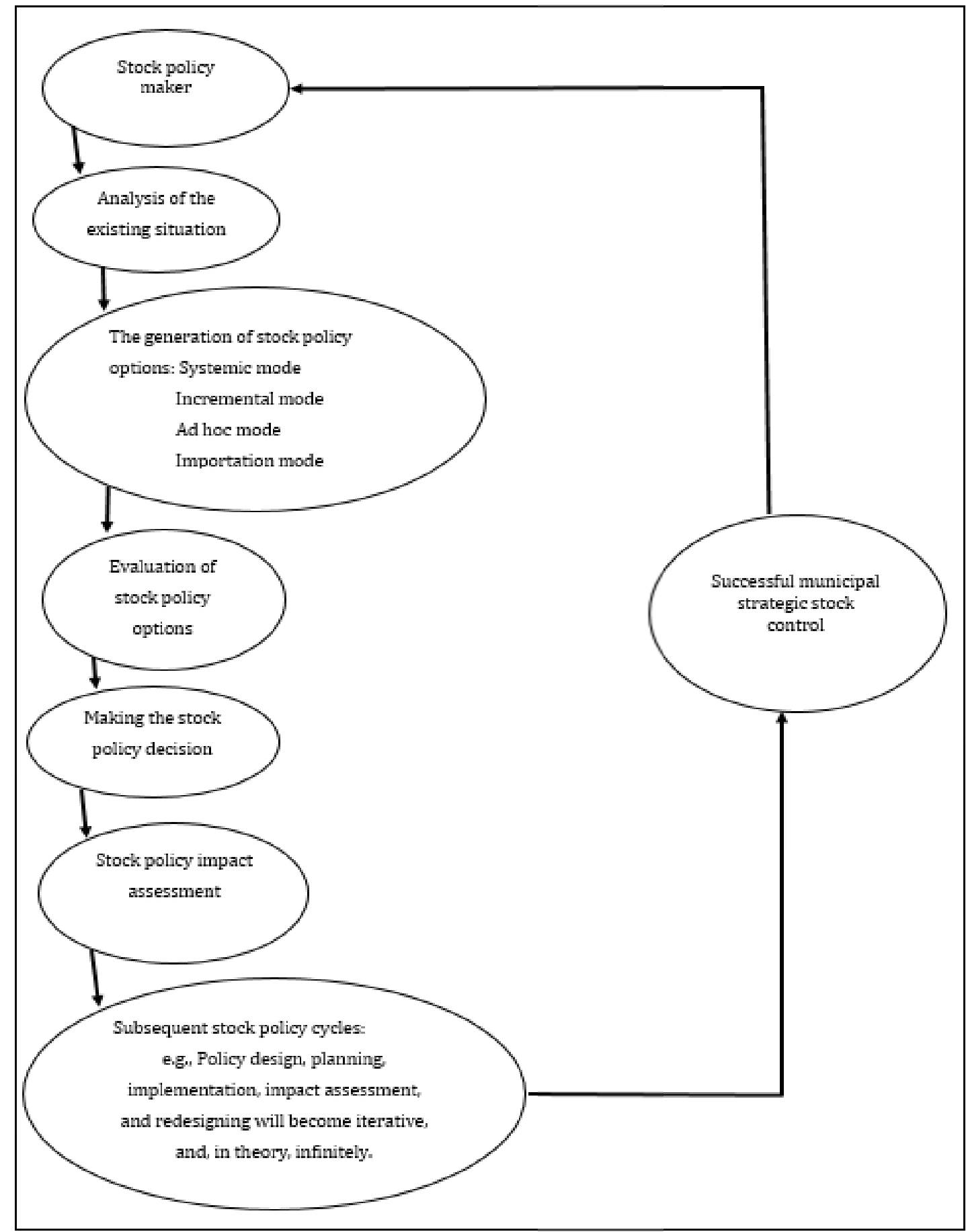

Fig. 2. Proposed CIMA stock control strategy framework for municipal stock control Source: self-generated. 